\title{
Ozone disrupts the communication between plants and insects in urban and suburban areas: an updated insight on plant volatiles
}

\author{
Noboru Masui ${ }^{1} \cdot$ Evgenios Agathokleous $^{2}$. \\ Tomoki Mochizuki ${ }^{3} \cdot$ Akira Tani $^{3}$. \\ Hideyuki Matsuura $^{4}$ Takayoshi Koike T,5 $^{4,5}$
}

Received: 1 August 2020 / Accepted: 29 October 2020 / Published online: 10 January 2021

(C) The Author(s) 2021

\begin{abstract}
Plant-insect interactions are basic components of biodiversity conservation. To attain the international Sustainable Development Goals (SDGs), the interactions in urban and in suburban systems should be better understood to maintain the health of green infrastructure. The role of ground-level ozone $\left(\mathrm{O}_{3}\right)$ as an environmental stress disrupting interaction webs is presented. Ozone mixing ratios in suburbs are usually higher than in the center of cities and may reduce photosynthetic productivity at a relatively higher degree. Consequently, carbon-based defense capacities of plants may be suppressed by elevated $\mathrm{O}_{3}$ more in the suburbs. However, contrary to this expectation, grazing damages by leaf beetles have been severe in some urban centers in comparison with the suburbs. To explain differences in grazing damages between urban areas and suburbs,
\end{abstract}

Project Funding: This work was supported financially by the Kuribayashi Scientific Foundation to Noboru Masui and The Startup Foundation for Introducing Talent of Nanjing University of Information Science \& Technology (NUIST), Nanjing, China (No. 003080)

The online version is available at http://www.springerlink.com.

Corresponding editor: Zhu Hong.

Supplementary information The online version of this article contains supplementary material available at (https://doi. org/10.1007/s11676-020-01287-4) to authorized users.

Noboru Masui

nmasui_agr@frontier.hokudai.ac.jp

1 Graduate School of Agriculture, Hokkaido University, Sapporo, Japan

2 Key Laboratory of Agrometeorology of Jiangsu Province, Institute of Ecology, School of Applied Meteorology, Nanjing University of Information Science \& Technology, Nanjing 210044, People's Republic of China the disruption of atmospheric communication signals by elevated $\mathrm{O}_{3}$ via changes in plant-regulated biogenic volatile organic compounds and long-chain fatty acids are considered. The ecological roles of plant volatiles and the effects of $\mathrm{O}_{3}$ from both a chemical and a biological perspective are presented. Ozone-disrupted plant volatiles should be considered to explain herbivory phenomena in urban and suburban systems.

Keywords Biological interactions $\cdot$ Elevated $\mathrm{O}_{3} \cdot$ Insect grazing $\cdot$ Pollination $\cdot$ Plant defense mechanisms

\section{Introduction}

Ozone $\left(\mathrm{O}_{3}\right)$ levels have been increasing in the last decades around the northern hemisphere, especially in east Asia (Koike et al. 2013; Akimoto et al. 2015; Feng et al. 2015, 2019a; Watanabe et al. 2017; Li et al. 2017; Nagashima et al. 2017). In general, suburban and rural areas exhibit higher average daily $\mathrm{O}_{3}$ levels than urban centers (Paoletti et al. 2014; Khan et al. 2017; Liu et al. 2019; Diaz et al. 2020) However, $\mathrm{O}_{3}$ pollution in cities has considerably increased in 2020 as a result of imposed lockdown measures due to COVID-19, suggesting potential temporal changes in the traditional differences in $\mathrm{O}_{3}$ concentrations between urban

3 School of Food and Nutritional Sciences, University of Shizuoka, Shizuoka, Japan

4 Research Faculty of Agriculture, Hokkaido University, Sapporo, Japan

5 Research Center for Eco-Environmental Science, CAS, Beijing 100085, People's Republic of China 
and suburban areas (Moser-Reischl 2019; Nakada and Urban 2020; Sharma et al. 2020; Sicard et al. 2020). Differences in $\mathrm{O}_{3}$ concentrations between urban and suburban areas indicate that plant-insect interactions can be affected differently.

It has been assumed that herbivory by insects is affected by physical or physiological responses of plant leaves to $\mathrm{O}_{3}$, which indirectly changes the lifecycle of insects, particularly under warmer climates (Duque et al. 2019). To date, research has focused on the $\mathrm{O}_{3}$ effect on the defensive capacity of plants, as suppression of defensive capacity leads to increased susceptibility to damage by insects. In recent research, serious insect grazing damages on avenue trees were found at relatively low $\mathrm{O}_{3}$ concentrations (urban centers) in northeast Asia, but such damages were not found on the same species at suburban sites with higher $\mathrm{O}_{3}$ levels (Takahashi et al. 2020). Plant-insect communication via biogenic volatile organic compounds (BVOCs) should be considered as a possible explanation for these observations (Agathokleous et al. 2020; Masui et al. 2020). Understanding plant-insect communications under changing atmospheric environments may help to conserve healthy forest ecosystems.

There are two roles for BVOCs: an atmospheric one and a chemical signaling one. Chemical signaling is a hub facilitating plant to plant and plant-insect communication in the environment, including in forest ecosystems (Penuelas and Llusia 2001; Heil and Bueno 2007; Trowbridge and Stoy 2013; Šimpraga et al. 2019). With regards to the atmospheric role, BVOCs contribute to $\mathrm{O}_{3}$ formation as $\mathrm{O}_{3}$ is generated from nitrogen oxides (NOx) via photochemical reactions with BVOCs under ultraviolet rays (UV) (Atkinson and Arey 2003; Kim et al. 2013; Akimoto et al. 2015). Photochemical smog, such as peroxy-acyl nitrate (PAN), is simultaneously generated thorough photochemical reaction and air pollution aggravates. VOCs act as catalytic substances in the photochemical reaction. In situations that the amount of NOx as a precursor substance of $\mathrm{O}_{3}$ is rapidly increasing due to industrial development, BVOCs are at the center of interest in atmospheric chemistry because global emissions of BVOCs surpass 10 times that of anthropogenic VOCs(Guenther et al. 2006; Kim et al. 2010; Im et al. 2011).

Chemical-signaling interactions via BVOCs between plants and plants/insects have biologically important roles in nature (Sharma et al. 2019). BVOCs are emitted to the atmosphere from leaves or flowers as scents (Dudareva and Pichersky 2008). There are some chemical group in these compounds; isoprene $\mathrm{C}_{5} \mathrm{H}_{8}$, a basic structure of BVOCs, monoterpene $\mathrm{C}_{10} \mathrm{H}_{16}$, sesquiterpene $\mathrm{C}_{15} \mathrm{H}_{24}$, while other chemically modified compounds like aldehyde or alcohol exist (Kesselmeier and Staudt 1999; Guenther et al. 2000). Although factors such as color and shape of flowers (and flower openness) contribute to their attractiveness, scent attracts insects from hundreds of meters, insects can locate their host plants by detecting unique volatile compounds or a unique blend of BVOCs (Šimpraga et al. 2016). Scent from flowers is a key factor to attract pollinators as well as herbivorous insects (Blüthgen and Klein 2011) in forest ecosystems as well (Šimpraga et al. 2019). Pollinators receive nectar and/or pollen as rewards from flowers, and pollinators and flowering plants are mutualistic (Kearns et al. 1998; Blüthgen and Klein 2011). Approximately 80-95\% of flowering species in the world benefit from insect pollinators (Ollerton et al. 2011). Without pollinators, most species cannot maintain their populations and expand their gene pool by cross-fertilization; thus pollinators support the formation and sustainability of forest ecosystems (Krishnan et al. 2020).

When insects graze on leaves, they use leaf volatiles to detect target plants (Trowbridge AM and Stoy 2013). Plant-insect communication influences the productivity of a forest but in case of the grazing on avenue trees in cities the grazing damage has a negative effect on the aesthetics. A study reported that damages by herbivores are responsible for losses of net primary production up to $15 \%$ in temperate forests (Lindroth 2010). However, plants do not remain passive to be grazed upon but may affect various types of insects, not only pests but also natural enemies of the pests. Plants often have different emissions, both in quality and quantity, after being stressed by biotic and abiotic factors, for example, by drought or high temperatures (Holopainen and Gershenzon 2010) as well as by grazing (Blande et al. 2007; Copolovici et al. 2011; Takabayashi and Shiojiri 2019). The different emissions after grazing by insects, called herbivore induced plant volatiles (HIPVs), have attractant effects (Bolter et al. 1997; Sun et al. 2012; Holopainen and Blande 2013), or repellent effects to the pests (De Moraes et al. 1998, 2001; Kessler and Baldwin 2001; Kloth et al. 2012; Holopainen and Blande 2013). The attractant effect of HIPVs means that the more the pests visit and graze, the more grazing damage deteriorates at an accelerating pace. On the other hand, when HIPVs have a repellent property, the host plant avoids further grazing, which is a type of direct induced-defense system via plant volatiles. Furthermore, included in an indirect-defense system, HIPVs attract natural enemies of the pests and indirectly limit grazing damage (Shimoda et al. 2002; Ammunét et al. 2009; Klemola et al. 2012; McCormick et al. 2012).

In some cases, plants prepare a volatiles-defense system by emitting volatiles that are repellent to pests or attractant to natural enemies of the pests even before being attacked. The reason why plants can prepare to cope with pests beforehand is attributed to plant-plant communication via BVOCs. When damaged plants emit unique BVOCs, non-damaged plants respond to the emissions as an emergency alert and increase the content of defensive compounds in the leaves (Himanen et al. 2010; Girón-Calva et al. 2016; Timilsena 
et al. 2020). Because of this plant-plant communication, the further spread of grazing damage can be inhibited while the pests seek other undamaged host plants.

A number of researchers point out the possibility that some insecticides disrupt the activity of insects making their habitat near agricultural areas as well as harming pollinators (Christen and Fent 2017; Friedli et al. 2020). This has become a major concern for the conservation of forest ecosystems coexisting with agricultural practices. However, even if the pests or pollinators are healthy, plant-insect communication can be disrupted due to external factors affecting BVOCs such as $\mathrm{O}_{3}$ (Agrell et al. 2005; McFrederick et al. 2009; Fuentes et al. 2013; Šimpraga et al. 2016; Masui et al. 2020). In addition, because suburban and rural areas have relatively high $\mathrm{O}_{3}$ concentrations, it is important to consider the possible disruption of plant-insect communication in these areas. Therefore, the effects of $\mathrm{O}_{3}$ on plant-insect communication in suburban areas should be given more attention. However, information on the effect of $\mathrm{O}_{3}$ on communication with BVOCs is limited (Fuentes et al. 2013; Blande et al. 2014; Saunier and Blande 2019; Brosset et al. 2020). Clarifying the communication webs in elevated $\mathrm{O}_{3}$ sites, e.g., suburban and rural areas, can helpto conserve healthy forest ecosystems under changing atmospheric environments. Furthermore, understanding the mechanism via plant volatiles will provide a perspective for other initiatives such as integrated pest management (IPM) (Vreysen 2005). In this paper, we discuss the roles of factors that regulate insect grazing activities, including defensive indicators of leaves, and focus on plant volatiles as a critical factor that may explain differences in plant-insect interactions between urban centers and suburbs.

\section{A parenthesis: the importance of pollinators in forests and agriculture}

Pollinating insects have a significant ecological role in maintaining forest ecosystems and agroforestry. Land use systems with forest woody perennials growing among or around cultivated agricultural crops (agroforestry) can promote ecological and economical balance and secure sustainable production, helping to address sustainable development goals. In addition to their ecological importance, pollinators provide great benefits to horticultural as well as to agricultural activities. Approximately $75 \%$ of crops humans depend on the activities of pollinators to maintain their productivity (Klein et al. 2007; Eilers et al. 2011). For example, honeybees and bumblebees, possibly the most representative pollinators, are often used in greenhouse cultivation. Not only do pollinators sustain crop productivities, but they are also powerful contributors to horticultural and agricultural farming because they perfectly execute time-consuming and expensive tasks that otherwise skilled personnel would need to perform.

In modern practice, forest patches and agricultural areas often exist in the same regions, particulary in suburban and rural areas. Forest areas usually provide habitats for pollinators that contribute to agricultural crops (Rivers et al. 2018) and vice versa. Therefore, such forestry and agricultural areas complement each other by facilitating pollination (Proesmans et al. 2019). If plant-pollinator interactions are disrupted, both forest ecosystems and agricultural activities may be suppressed.

\section{What factor is important for insect grazing under elevated $\mathrm{O}_{3}$ ?}

\section{$\mathrm{O}_{3}$ effects on physical defensive systems}

Generally, leaf mass per unit area (hereafter LMA) is an indicator of physical defense to insect herbivory (Koike et al. 2006; de la Riva et al. 2016). Low LMA values mean that leaves may be easily grazed and high values that leaves may be more protected (Yamasaki and Kikuzawa 2003; Howe and Jander 2008; War et al. 2012). Elevated $\mathrm{O}_{3}$ levels suppress photosynthetic activities (Sitch et al. 2007; Koike et al. 2013; Watanabe et al. 2017; Grulke and Heath 2020), and photosynthesis is strongly correlated with LMA (Koike 1988; Poorter et al. 2009), meaning that elevated $\mathrm{O}_{3}$ can decrease LMA through physiological responses ( $\mathrm{Li}$ et al. 2015; Shang et al. 2017).

Trichomes are also a physical defense mechanism and are specific cell constructions on the epidermal layer of leaves (e.g., hairs). They are classified into glandular and non-glandular trichomes, and provide a means for plants to defend against stresses, both abiotic (e.g., drought, freezing, UV radiation, $\mathrm{O}_{3}$ ) and biotic (e.g., pathogens, insects) (Koike et al. 2006; Hauser 2014; Oksanen 2018). For $\mathrm{O}_{3}$ stress, glandular trichomes reduce $\mathrm{O}_{3}$ uptake, while non-glandular trichomes do not have such a defensive role against $\mathrm{O}_{3}(\mathrm{Li}$ et al. 2018; Oksanen 2018). With regards to herbivory, the presence of trichomes influences insect oviposition and/ or feeding by various species (Vermeij 2015; Oksanen 2018). For example, trichomes interfere with insect mobility because of their morphology and also contribute to the depression effect of toxic chemicals such as phenolics that reduce the nutritional value of leaves (Matsuki et al. 2004; Schoonhoven et al. 2005; Karabourniotis et al. 2020). Both types of trichomes function as a defensive system but may not necessarily protect against the same herbivorous insect species; glandular trichomes may prevent the herbivory of an insect but may not prevent the herbivory of another which may only be prevented by a high density of non-glandular trichomes (Matsuki et al. 2004; Tian et al. 2012). Leaves 
under elevated $\mathrm{O}_{3}$ may already have a high density of glandular trichomes which act as a barrier against herbivory. Whether $\mathrm{O}_{3}$ induces high density glandular and/or nonglandular trichomes remains still unclear. However, there is evidence that a rapid change in glandular trichome density can occur in response to frost and to $\mathrm{O}_{3}$ to enhance plant tolerance, although with high variations among ecotypes of species (Prozherina et al. 2003). It was noteworthy that a shift from glandular to non-glandular trichomes was caused by increased defoliation in birch (Rautio et al. 2002).

\section{$\mathrm{O}_{3}$ effects on chemical defensive systems}

Plant chemical defensive compounds such as condensed tannins, lignin, and phenolics are mostly carbon-based compounds regulated by photosynthesis (e.g. Schoonhoven et al. 2005). According to the carbon-nutrient balance (CNB) hypothesis, allocation of carbon to defensive systems becomes lower in order to keep sufficient resources for growth when plants are growing in nitrogen-rich soils and/or in conditions not favoring photosynthesis, e.g., under shade or the presence of other environmental stresses (Schoonhoven et al. 2005). Elevated $\mathrm{O}_{3}$ can suppress photosynthesis and lead to decreased carbon-based defense capacities, such as condensed tannins or phenolics (Matyssek et al. 2012; Sugai et al. 2020). According to the growth differentiation balance (GDB) hypothesis, some plants show a high growth rate in order to compete with other plants and to compensate for herbivorous damage, rather than allocating resources to defense when growing in an optimum environment with high availability of soil nutrients and adequate light (Herms and Mattson 1992).

In contrast, in environments with inadequate growing conditions, plants have higher levels of defensive metabolites (Fig. 1; Schoonhoven et al. 2005; Matyssek et al. 2012; Cipollini et al. 2014). In the case of early successional species with high light demands, trees allocate their photosynthates more to growth than to defense during sapling to adult stage (Koike et al. 2006). Moreover, when trees are affected by atmospheric conditions decreasing photosynthetic efficiency such as $\mathrm{O}_{3}$, defensive capacities become more aggravated.

An important development in understanding the mechanism is the recognition that plant responses to $\mathrm{O}_{3}$ do not commonly follow a linear non-threshold model but widely follow a hormetic model (Agathokleous et al. 2019a; Bellini and De Tullio 2019; Duque et al. 2019). Ozone exposure inhibits physiological activities, however, suppression starts from a certain threshold level of exposure depending on the plant species (Agathokleous et al. 2019a). Based on the hormetic model (Agathokleous 2018, 2019a), low $\mathrm{O}_{3}$ concentrations, (slightly above the concentrations that plants are adapted to) can induce positive effects, including enhanced photosynthesis, and improved photosystem functioning, resulting in higher leaf areas and/or enhancement of defensive capacities by trees and other plant species. These suggest that $\mathrm{O}_{3}$ effects on leaf quality is not a one-way but a two-way direction.

\section{Limitation of traditional discussion in explaining plant-insect interactions based on foliage quality}

Generally, it has been assumed that insect behavior is linked to the defensive properties of leaves (e.g. Bryant et al. 1983; Fürstenberg-Hägg et al. 2013; Agathokleous et al. 2019b). Low physical and chemical defensive properties indicate that insects can graze a plant more easily. Choice and nochoice laboratory feeding assays showed that alder leaf beetle, an oligophagous pest of alder and birch, preferred grazing elevated $\mathrm{O}_{3}$ leaves (over ambient $\mathrm{O}_{3}$ leaves) when birch leaves had low contents of condensed tannin and phenolics under elevated $\mathrm{O}_{3}$ (Sakikawa et al. 2016; Agathokleous et al. 2017). However, this phenomenon was not found in the field. In the field, leaf beetles grazed Japanese white birch individuals in ambient $\mathrm{O}_{3}$ plots more than in elevated $\mathrm{O}_{3}$ plots, although it would have been expected that the ozonated leaves would have been preferred based on laboratory
Fig. 1 Relationship between defensive capacity of plants and environmental conditions; $\mathrm{C}$ is carbon and $\mathrm{N}$ is nitrogen (illustrated from Schoonhoven et al. 2005)

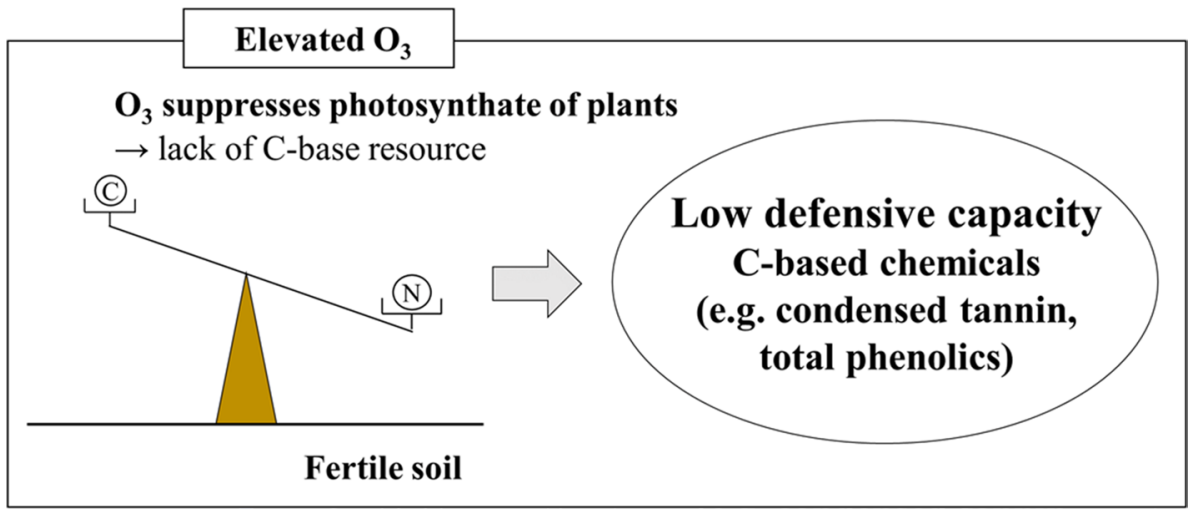


assays (Sakikawa et al. 2016; Agathokleous et al. 2017; Abu ElEla et al. 2018). To date, much research of $\mathrm{O}_{3}$ effects on herbivory insects has focused on the relationship between the physiological response (photosynthesis, allocation of carbon products and nutrients) of plants and insect grazing (Manninen et al. 2000; Holton et al. 2003; Kopper and Lindroth 2003; Agrell et al. 2005; Hamilton et al. 2005; Matyssek et al. 2012; Agathokleous et al. 2017; Bubica Bustos et al. 2020). However, it is difficult to explain herbivory based on only foliage quality. Hence, apart from leaf interiors, other leaf-exterior factors potentially affected by $\mathrm{O}_{3}$ should be identified. For instance, plant volatiles are a major leaf-exterior factor that is now receiving increasing interest.

\section{New explanations: plant volatiles regulate insect grazing}

\section{BVOCs under elevated $O_{3}$ : long-distance signals}

BVOCs can attract or repel pests and pollinators, creating an important communication platform for agroforestry ecosystems (Takabayashi and Shiojiri 2019). The effect of $\mathrm{O}_{3}$ on BVOCs is divided into two types: (1) alteration of BVOCs emissions (an effect on plant metabolism), and (2) post-emission disruption of BVOCs in the atmosphere. In the former, BVOCs emissions can be negatively or positively affected by elevated $\mathrm{O}_{3}$, potentially altering the behavior of insects that detect the BVOCs and orient to space. There are some tree species that significantly change their emissions due to $\mathrm{O}_{3}$, while others show little or no effect, depending on the volatile compounds (Blande et al. 2007; Holopainen and Gershenzon 2010; Xu et al. 2015; Tani et al. 2017; Bison et al. 2018; Miyama et al. 2018). It should be noted that the response of BVOC emissions to elevated $\mathrm{O}_{3}$ is dynamic and non-linear, often biphasic (Agathokleous et al. 2018). For example, in silver birch (Betula pendula Roth), the emission of some volatile compounds were reduced at lower $\mathrm{O}_{3}$ levels but increased at higher levels (Carriero et al. 2016; Agathokleous et al. 2018). A literature meta-analysis revealed that isoprene emission is more affected by elevated $\mathrm{O}_{3}$ than monoterpenes (Feng et al. 2019b).

Whether BVOC emissions are affected by elevated $\mathrm{O}_{3}$ or not, post-emitted BVOCs in the atmosphere can be disrupted by $\mathrm{O}_{3}$. The lifetime of each BVOC, which ranges from a minute to hours or days, is affected by air pollutants, including $\mathrm{O}_{3}$ (Fuentes et al. 2000; Atkinson and Arey 2003; Arneth and Niinemets 2010). Atmospheric chemistry developments show that many volatile substances are highly reactive with $\mathrm{O}_{3}$. For example, the lifetime of limonene, a monoterpene, can be shorter under elevated $\mathrm{O}_{3}$ than one under ambient $\mathrm{O}_{3}$, ranging from $2 \mathrm{~h}$ at $26 \mathrm{nmol} \mathrm{mol}^{-1} \mathrm{O}_{3}$ to about $40 \mathrm{~min}$ at $73 \mathrm{nmol} \mathrm{mol}^{-1}$ (Masui et al. 2020). The mechanism of shortened lifetime in elevated $\mathrm{O}_{3}$ may be explained by a structural disruption of BVOCs through an oxidizing reaction of the double-bond structure (Llusià et al. 2002; Atkinson and Arey 2003; Pinto et al. 2010). In this case, BVOCs functional role within an ecosystem is altered. If the attractant compounds show high reactivity with $\mathrm{O}_{3}\left(\mathrm{O}_{3}\right.$-reactive compounds), insects can be easily disoriented and wander away from their host plants in elevated $\mathrm{O}_{3}$ (Fuentes et al. 2013; Blande et al. 2014; Masui et al. 2020). In addition, oxidative products via reaction can show repellent effects to some insects (Glinwood et al. 2003; Mishra and Sihag 2010; Holopainen and Blande 2013), thus, the entire ecosystem may be affected by $\mathrm{O}_{3}$ via BVOCs communication.

Chemical analysis of plant volatiles is an important explanatory factor to consider. The evaluation of $\mathrm{O}_{3}$-reactive compounds is particularly necessary because there is a high possibility that these contribute to behavioral changes of insects. The composition of BVOCs depends on tree species, even in the same genus, i.e., some species emit only a few dominant compounds while others have diverse emissions, including monoterpenes (MT), sesquiterpenes (SQT), and others (Calfapietra et al. 2009; Loreto et al. 2009; Simpson and McPherson 2011). For species whose BVOCs composition has not been as yet clarified, BVOCs sampling and analysis are first needed. Moreover, heterophyllous species, ones that have leaves of more than one form on the same branch like birch (Betula sp.), show different physiological traits between early and late leaves (Matsuki et al. 2004; Koike et al. 2006; Agathokleous et al. 2017). Similarly, differences between early and late leaves may also be found in BVOCs emissions. BVOCs sampling has to be arranged with the phenology of herbivorous insects and heterophyllous species at the same time.

By comparing BVOCs among tree species that pests commonly graze (positive controls), compounds of high importance for the attractant property can be found. There are numerous studies that have clarified the composition of BVOCs of targeted trees but only showed the BVOCs profile, being often difficult to refer to the relationship between BVOCs and insect behavior in detail (Killiny and Jones 2017; Fancelli et al. 2018). If there is a distinct compound emission, it is easily identified and verification can proceed. However, in most cases it is assumed that the attractant property is more attributed to a combination of several compounds (Bruce et al. 2005). Thus, BVOC analyses over multiple species, including negative controls, can help to detect common BVOC combination among positive controls (BVOCs sampling and measurement is described in Supplementary Information). For example, in birch, whose main pest is the alder leaf beetle, Japanese white birch (Betula platyphylla var. japonica Hara) and alder (Alnus japonica (Thunb.) Steud) are positive controls; Japanese rowan (Sorbus commixta Hedl) and Korean mulberry (Morus australis 
Poiret) are negative controls that grow in the same area and time with positive controls in Hokkaido, Japan (Masui et al. unpublished).

\section{Long-chain fatty acids under elevated $\mathrm{O}_{3}$; short-distance signals}

Long-chain fatty acids (LCFAs) and their composition can also regulate the behavior of insects via oxidation by elevated $\mathrm{O}_{3}$ (Manosalva et al. 2011). LCFAs are not included in BVOCs but they function as signal chemicals. In previous studies, female adult beetles of Hylastinus obscurus Marsh. (Coleoptera: Chrysomelidae) were attracted to LCFAs lauric, palmitic and oleic fatty acids, and red pumpkin beetle (Aulacophora foveicollis Lucas) to myristic, palmitoleic, $\alpha$-linolenic, and nonadecanoic acids (Mukherjee and Barik 2014). Females are assumed to be more attracted to olfactory signals than males because they have to detect host plants for oviposition as well as for feeding (Mukherjee and Barik 2014). Because of the low volatility of LCFAs, insects sense them from shorter distances (Manosalva et al. 2011) compared with BVOCs. Thus, it is possible that LCFAs enable insects to detect host plants after being attracted by BVOCs from a long distance. In addition, oviposition of insects can be influenced by LCFAs on the surface of the oviposition site such as seeds or leaves (Parr et al. 1998; Li and Ishikawa 2006). Although it is still unknown how LCFAs react with $\mathrm{O}_{3}$ in the atmosphere as BVOCs do, the amount of LCFAs in the tissue of leaves can be decreased by $\mathrm{O}_{3}$ uptake, which means decreased olfactory information for insects to detect.

Comparisons between pre- and post-exposure to $\mathrm{O}_{3}$ based on a GC/MS analysis, shows the dynamics of LCFA composition in elevated $\mathrm{O}_{3}$. Previously, the relationship was studied by evaluating malondialdehyde (MDA), an indicator of lipid peroxidation (Calatayud et al. 2003; Cassimiro and Moraes 2016). However, the actual changes to compounds by $\mathrm{O}_{3}$ have not, as yet, been well researched. Furthermore, the effect of long-term $\mathrm{O}_{3}$ exposure to plants in open-field experiments remains unknown. For example, the GC/MS for major LCFAs, such as palmitic acid $\left(\mathrm{C}_{16: 0}\right)$, linolenic acid $\left(\mathrm{C}_{18: 3}\right)$, linoleic acid $\left(\mathrm{C}_{18: 2}\right)$, oleic acid $\left(\mathrm{C}_{18: 1}\right)$ and stearic acid $\left(\mathrm{C}_{18: 0}\right)$ can be relatively easily analyzed with standard samples.

\section{Olfactory response test}

Several studies have examined whether elevated $\mathrm{O}_{3}$ exposure can disrupt plant-insect communication (Fuentes et al. 2016; Girón-Calva et al. 2016; Agathokleous et al. 2017; Mofikoya et al. 2018; Sugai et al. 2020). These studies support the observation that the degradation of BVOCs by elevated $\mathrm{O}_{3}$ is a key driver of the disruption. To support the results in the field and to identify the attractant or repellent property of each BVOC, olfactory response tests are needed. One of the tests is electroantennography (EAG), which enables the detection of whether each compound is active on the insect's antennae (Bruce et al. 2005; Fernandez and Hilker 2007; Feng et al. 2017; Germinara et al. 2019; Iovinella et al. 2020). EAG analysis is a remarkable and useful technique for olfactory experiments; however, it does not indicate whether the insect is attracted or repelled by a compound and does not show the function of BVOCs, including all volatile compounds from plants. The Y-tube olfactometer, (Y-tube preference test), is a simpler and more effective method in vitro. In this test, air A (with BVOCs) flowing from a side of an arm and air $\mathrm{B}$ (BVOCs mixed with $\mathrm{O}_{3}$ ) from the other arm at the same flow rate, an insect has the task to move from the mouth of Y-shaped glass tube and select one of the two arms (Air A or Air B) to visit (Takabayashi and Dicke 1992; Shimoda et al. 1997; 2002; Brilli et al. 2009; Fuentes et al. 2013; Mukherjee et al. 2014; Masui et al. 2020). Attractant properties of BVOCs can be demonstrated by simultaneously comparing two conditions, e.g. an ambient $\mathrm{O}_{3}$ level vs an elevated $\mathrm{O}_{3}$ level that is artificially created (Pinto et al. 2007a, b). The Y-tube test can provide clear results of BVOCs as phenomenon in close-toreality simulation.

\section{Plant-insect communication through plant volatiles under elevated $\mathrm{O}_{3}$}

If olfactory cues show an attractant property, insects can visit and foliage quality secondarily will affect the feeding insects (Fig. 2). In contrast, if $\mathrm{O}_{3}$ disrupts BVOC signals from plants to insects, or the BVOCs act as a repellent, insects may not be able to visit and thus, the chemical and physical defense of leaves do not play any role in plant-insect interaction, regardless of the actual quality. Therefore, in addition to the traditional insight of leaves as a feeding source, the effect of $\mathrm{O}_{3}$ on plant volatiles as olfactory cues should be taken into consideration when plant herbivory under elevated $\mathrm{O}_{3}$ is studied in the future. The Y-tube preference test, as a biological assay, can show the role of plant volatiles (Fuentes et al. 2013; Masui et al. 2020) and the changes under polluted air. Furthermore, by chemical analysis (e.g., using GC/ MS) to identify important profiles for attractants of BVOCs, a better understanding of the interaction between $\mathrm{O}_{3}$ and plant volatiles can be achieved.

\section{Conclusions and perspectives}

The considerable temporary increase in $\mathrm{O}_{3}$ pollution in cities worldwide subjected to "lockdown" against the spreading of the severe acute respiratory syndrome coronavirus 


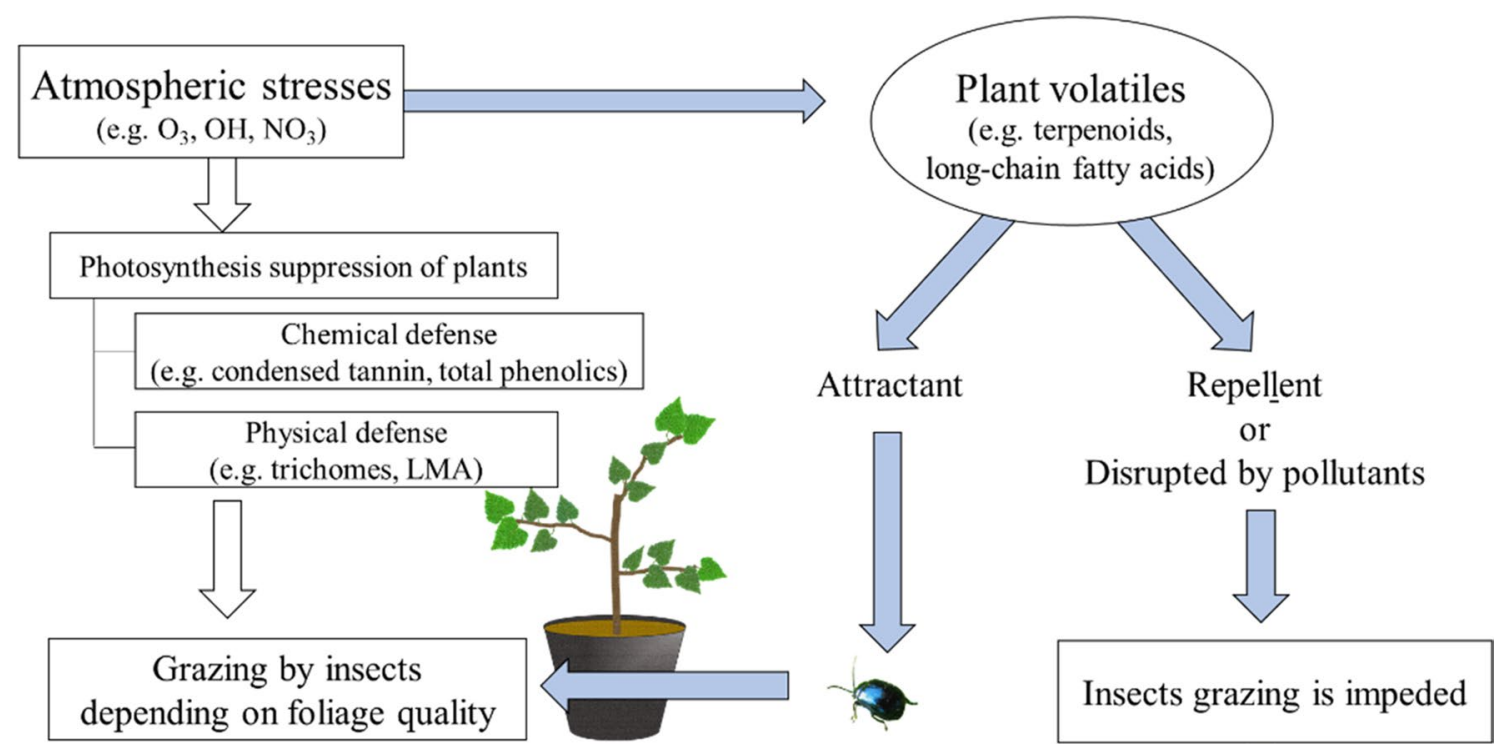

Fig. 2 A new insight into the behavior of insects with plant volatiles under elevated $\mathrm{O}_{3}$. White arrows indicate traditional discussion for herbivory explained with foliage qualities such as defensive capacities. The processes indicated by white arrows mean an explanation

2 (SARS-CoV-2) (Nakada and Urban 2020; Sharma et al. 2020; Sicard et al. 2020) suggests that plant-insect interactions in urban and suburban agroforestry systems may be threatened in a shorter term due to rapid changes in anthropogenic activities.

Most studies on plant-insect interactions under $\mathrm{O}_{3}$ have been carried out in urban and suburban areas. This creates an important knowledge gap of $\mathrm{O}_{3}$ effects on plant-insect communication in remote/rural and mountainous natural forests, and especially at high altitudes, considering that $\mathrm{O}_{3}$ concentrations tend to increase with increasing altitude and that high altitudes have considerably higher $\mathrm{O}_{3}$ levels than low altitudes (Schultz et al. 2017; Saitanis et al. 2020). Hence, studies of how $\mathrm{O}_{3}$ affects plant-insect interaction at high altitudes are also needed.

Recently considerable research of $\mathrm{O}_{3}$ effects on plant volatiles have been carried out on agricultural crops (Fuentes et al. 2013; Farré-Armengol et al. 2016; Khaling et al. 2016, 2020; Acton et al. 2018; Mofikoya et al. 2018; Agathokleous et al. 2019b; Duque et al. 2019). Although there are some recent studies on $\mathrm{O}_{3}$ effects on forest tree volatiles (Xu et al. 2015, 2019; Yuan et al. 2020), the studies remain much fewer relatively to crops. This lack of studies with trees may be attributed to the practical difficulty in conducting such experiments with trees (in $\mathrm{O}_{3}$-FACE systems) in terms of time, effort and resources needed. New studies of plant volatiles with forest and avenue trees should be conducted to conserve healthy forest ecosystems in different environments facing the threat of elevated $\mathrm{O}_{3}$. with traditional discussion and blue arrows mean new processes with plant volatiles, incorporated to traditional discussion as shown in main text

In conclusion, biological communication via plant volatiles (biogenic volatile organic compounds, long-chain fatty acids) between plants and insects in urban and suburban areas should be of concern. Traditional discussions were based on foliage quality (leaf mass/unit area, condensed tannin, phenolics, lignin, nitrogen content), which was rightly assumed to directly affect pests, pollinators, and natural enemies. However, a new insight based on communication between plants and insects should be also considered. Plant volatiles as olfactory cues can be altered by air pollutants such as $\mathrm{O}_{3}$ in the atmosphere, thereby altering the activity of insects before they arrive at the leaves and are affected by the chemical and physical foliage quality. This review serves as the basis to encourage further studies based on this insight centered on plant-insect communication via plant volatiles.

Acknowledgements Dr. Takayoshi Koike thanks for the financial support in part by the Ministry of Environment of Japan, JSPS and JST Grant No. JPMJSC18HB (through Prof. T. Watanabe of Hokkaido Univ.)

Open Access This article is licensed under a Creative Commons Attribution 4.0 International License, which permits use, sharing, adaptation, distribution and reproduction in any medium or format, as long as you give appropriate credit to the original author(s) and the source, provide a link to the Creative Commons licence, and indicate if changes were made. The images or other third party material in this article are included in the article's Creative Commons licence, unless indicated otherwise in a credit line to the material. If material is not included in the article's Creative Commons licence and your intended use is not permitted by statutory regulation or exceeds the permitted use, you will need to obtain permission directly from the copyright holder. To view a copy of this licence, visit http://creativecommons.org/licenses/by/4.0/. 


\section{References}

Abu ElEla SA, Agathokleous E, Koike T (2018) Growth and nutrition of Agelastica coerulea (Coleoptera: Chrysomelidae) larvae changed when fed with leaves obtained from an $\mathrm{O}_{3}$-enriched atmosphere. Environ Sci Pollut Res 25(13):13186-13194. https ://doi.org/10.1007/s11356-018-1683-1

Acton WJF, Jud W, Ghirardo A, Wohlfahrt G, Hewitt CN, Taylor JE, Hansel A (2018) The effect of ozone fumigation on the biogenic volatile organic compounds (BVOCs) emitted from Brassica napus above- and below-ground. PLoS ONE 13(12):1-19. https ://doi.org/10.1371/journal.pone.0208825

Agathokleous E (2018) Environmental hormesis, a fundamental nonmonotonic biological phenomenon with implications in ecotoxicology and environmental safety. Ecotoxicol Environ Saf 148:1042-1053. https://doi.org/10.1016/j.ecoenv.2017.12.003

Agathokleous E, Belz RG, Calatayud V, De Marco A, Hoshika Y, Kitao M, Saitanis CJ, Sicard P, Paoletti E, Calabrese EJ (2019a) Predicting the effect of ozone on vegetation via linear nonthreshold (LNT), threshold and hormetic dose-response models. Sci Total Environ 649:61-74. https://doi.org/10.1016/j.scito tenv.2018.08.264

Agathokleous E, Feng Z, Oksanen E, Sicard P, Wang Q, Saitanis CJ, Araminiene V, Blande JD, Hayes F, Calatayud V, Domingos M, Veresoglou SD, Peñuelas J, Wardle DA, De Marco A, Li Z, Harmens H, Yuan X, Vitale M, Paoletti E (2020) Ozone affects plant, insect, and soil microbial communities: a threat to terrestrial ecosystems and biodiversity. Sci Adv 6:eabc1176. https:// doi.org/10.1126/sciadv.abc1176

Agathokleous E, Kitao M, Calabrese EJ (2018) Emission of volatile organic compounds from plants shows a biphasic pattern within an hormetic context. Environ Pollut 239:318-321. https://doi. org/10.1016/j.envpol.2018.04.031

Agathokleous E, Sakikawa T, Abu ElEla SA, Mochizuki T, Nakamura M, Watanabe M, Kawamura K, Koike T (2017) Ozone alters the feeding behavior of the leaf beetle Agelastica coerulea (Coleoptera: Chrysomelidae) into leaves of Japanese white birch (Betula platyphylla var. japonica). Environ Sci Pollu Res 24(21):1757717583. https://doi.org/10.1007/s11356-017-9369-7

Agathokleous E, WaiLi Y, Ntatsi G, Konno K, Saitanis CJ, Kitao M, Koike T (2019b) Effects of ozone and ammonium sulfate on cauliflower: emphasis on the interaction between plants and insect herbivores. Sci Total Environ 659:995-1007. https://doi. org/10.1016/j.scitotenv.2018.12.388

Agrell J, Kopper B, McDonald EP, Lindroth RL (2005) $\mathrm{CO}_{2}$ and $\mathrm{O}_{3}$ effects on host plant preferences of the forest tent caterpillar (Malacosoma disstria). Glob Chang Biol 11(4):588-599. https ://doi.org/10.1111/j.1365-2486.2005.00924.x

Akimoto H, Mori Y, Sasaki K, Nakanishi H, Ohizumi T, Itano Y (2015) Analysis of monitoring data of ground-level ozone in Japan for long-term trend during 1990-2010: causes of temporal and spatial variation. Atmos Environ 102:302-310. https://doi. org/10.1016/j.atmosenv.2014.12.001

Ammunét T, Klemola N, Heisswolf A, Klemola T (2009) Larval parasitism of the autumnal moth reduces feeding intensity on the mountain birch. Oecologia 159(3):539-547. https://doi. org/10.1007/s00442-008-1240-6

Arneth A, Niinemets Ü (2010) Induced BVOCs: how to bug our models? Trends Plant Sci 15(3):118-125. https://doi.org/10.1016/j. tplants.2009.12.004

Atkinson R, Arey J (2003) Gas-phase tropospheric chemistry of biogenic volatile organic compounds:a review. Atmos Environ 37(2):197-219. https://doi.org/10.1016/S1352-2310(03)00391-1
Bellini E, De Tullio MC (2019) Ascorbic acid and ozone: novel perspectives to explain an elusive relationship. Plants 8(5):1-12. https://doi.org/10.3390/plants8050122

Bison JV, Cardoso-Gustavson P, De Moraes RM, da Silva PG, Cruz LS, Freschi L, de Souza SR (2018) Volatile organic compounds and nitric oxide as responses of a Brazilian tropical species to ozone: the emission profile of young and mature leaves. Environ Sci Pollut Res 25(4):3840-3848. https://doi.org/10.1007/s1135 6-017-0744-1

Blande JD, Holopainen JK, Niinemets Ü (2014) Plant volatiles in polluted atmospheres: stress responses and signal degradation. Plant Cell Environ 37(8):1892-1904. https://doi.org/10.1111/ pce. 12352

Blande JD, Tiiva P, Oksanen E, Holopainen JK (2007) Emission of herbivore-induced volatile terpenoids from two hybrid aspen ( $\mathrm{Popu-}$ lus tremula $\times$ tremuloides) clones under ambient and elevated ozone concentrations in the field. Glob Chang Biol 13(12):25382550. https://doi.org/10.1111/j.1365-2486.2007.01453.x

Blüthgen N, Klein AM (2011) Functional complementarity and specialisation: the role of biodiversity in plant-pollinator interactions. Basic Appl Ecol 12(4):282-291. https://doi.org/10.1016/j. baae.2010.11.001

Bolter CJ, Dicke M, Van Loon JJA, Visser JH, Posthumus MA (1997) Attraction of Colorado potato beetle to herbivore-damaged plants during herbivory and after its termination. J Chem Ecol 23(4):1003-1023. https://doi.org/10.1023/B:JOEC.0000006385 $.70652 .5 \mathrm{e}$

Brilli F, Ciccioli P, Frattoni M, Prestininzi M, Spanedda AF, Loreto F (2009) Constitutive and herbivore-induced monoterpenes emitted by Populus $\times$ euroamericana leaves are key volatiles that orient Chrysomela populi beetles. Plant Cell Environ 32(5):542-552. https://doi.org/10.1111/j.1365-3040.2009.01948.x

Brosset A, Saunier A, Kivimäenpää M, Blande JD (2020) Does ozone exposure affect herbivore-induced plant volatile emissions differently in wild and cultivated plants? Environ Sci Pollut Res 27:30448-30459. https://doi.org/10.1007/s11356-020-09320-z

Bruce TJA, Wadhams LJ, Woodcock CM (2005) Insect host location: a volatile situation. Trends Plant Sci 10(6):269-274. https://doi. org/10.1016/j.tplants.2005.04.003

Bryant JP, Chapin FS, Klein DR (1983) Carbon/nutrient balance of boreal plants in relation to vertebrate herbivory. Oikos 40:357368. https://doi.org/10.2307/3544308

Bubica Bustos LM, Ueno AC, Di Leo TD, Crocco CD, MartínezGhersa MA, Molina-Montenegro MA, Gundel PE (2020) Maternal exposure to ozone modulates the endophyte-conferred resistance to aphids in Lolium multiflorum plants. Insects 11(9):548. https://doi.org/10.3390/insects11090548

Calatayud A, Iglesias DJ, Talón M, Barreno E (2003) Effects of 2-month ozone exposure in spinach leaves on photosynthesis, antioxidant systems and lipid peroxidation. Plant Physiol Biochem 41(9):839-845. https://doi.org/10.1016/S0981 -9428(03)00123-2

Calfapietra C, Fares S, Loreto F (2009) Volatile organic compounds from Italian vegetation and their interaction with ozone. Environ Pollut 157(5):1478-1486. https://doi.org/10.1016/j.envpo 1.2008.09.048

Carriero G, Brunetti C, Fares S, Hayes F, Hoshika Y, Mills G, Tattini M, Paoletti E (2016) BVOC responses to realistic nitrogen fertilization and ozone exposure in silver birch. Environ Pollut 213:988-995. https://doi.org/10.1016/j.envpol.2015.12.047

Cassimiro JC, Moraes RM (2016) Responses of a tropical tree species to ozone: visible leaf injury, growth, and lipid peroxidation. Environ Sci Pollut Res 23(8):8085-8090. https://doi. org/10.1007/s11356-015-5961-x 
Christen V, Fent K (2017) Exposure of honey bees (Apis mellifera) to different classes of insecticides exhibit distinct molecular effect patterns at concentrations that mimic environmental contamination. Environ Pollut 226:48-59. https://doi.org/10.1016/j. envpol.2017.04.003

Cipollini D, Walters D, Voelckel C (2014) Costs of resistance in plants: from theory to evidence. Annu Plant Rev 47:263-307. https://doi.org/10.1002/9781119312994.apr0512

Copolovici L, Kännaste A, Remmel T, Vislap V, Niinemets Ü (2011) Volatile emissions from Alnus glutionosa induced by herbivory are quantitatively related to the extent of damage. J Chem Ecol 37(1):18-28. https://doi.org/10.1007/s10886-010-9897-9

de la Riva EG, Olmo M, Poorter H, Ubera JL, Villar R (2016) Leaf mass per area (LMA) and its relationship with leaf structure and anatomy in 34 mediterranean woody species along a water availability gradient. PLoS ONE 11(2):1-18. https:// doi.org/10.1371/journal.pone.0148788

De Moraes CM, Lewis WJ, Pare PW, Alborn HT, Tumlinson JH (1998) Herbivore-infested plants selectively attract parasitoids. Nature 393(11):570-573. https://doi.org/10.1038/31219

De Moraes CM, Mescher MC, Tumlinson JH (2001) Caterpillarinduced nocturnal plant volatiles repel conspecific females. Nature 410:577-579. https://doi.org/10.1038/35069058

Diaz FMR, Khan MAH, Shallcross BMA, Shallcross EDG, Vogt U, Shallcross DE (2020) Ozone trends in the United Kingdom over the last 30 years. Atmosphere 11(5):1-14. https://doi. org/10.3390/atmos11050534

Dudareva N, Pichersky E (2008) Metabolic engineering of plant volatiles. Curr Opin Biotechnol 19(2):181-189. https://doi. org/10.1016/j.copbio.2008.02.011

Duque L, Poelman EH, Steffan-Dewenter I (2019) Plant-mediated effects of ozone on herbivores depend on exposure duration and temperature. Sci Rep 9(1):1-11. https://doi.org/10.1038/ s41598-019-56234-z

Eilers EJ, Kremen C, Greenleaf SS, Garber AK, Klein AM (2011) Contribution of pollinator-mediated crops to nutrients in the human food supply. PLoS ONE 6(6):e21363. https://doi. org/10.1371/journal.pone.0021363

Fancelli M, Borges M, Laumann RA, Pickett JA, Birkett MA, Blassioli-Moraes MC (2018) Attractiveness of host plant volatile extracts to the Asian Citrus Psyllid, Diaphorina citri, is reduced by terpenoids from the non-host cashew. J Chem Ecol 44(4):397-405. https://doi.org/10.1007/s10886-018-0937-1

Farré-Armengol G, Peñuelas J, Li T, Yli-Pirilä P, Filella I, Llusia J, Blande JD (2016) Ozone degrades floral scent and reduces pollinator attraction to flowers. New Phytol 209(1):152-160. https://doi.org/10.1111/nph.13620

Feng B, Qian K, Du YJ (2017) Floral volatiles from vigna unguiculata are olfactory and gustatory stimulants for oviposition by the bean pod borer moth maruca vitrata. Insects. https://doi. org/10.3390/insects8020060

Feng Z, De Marco A, Anav A, Gualtieri M, Sicard P, Tian H, Fornasier F, Tao F, Guo A, Paoletti E (2019a) Economic losses due to ozone impacts on human health, forest productivity and crop yield across China. Environ Int. https://doi.org/10.1016/j. envint.2019.104966

Feng Z, Paoletti E, Bytnerowicz A, Harmens H (2015) Ozone and plants. Environ Pollut 202:215-216. https://doi.org/10.1016/j. envpol.2015.02.004

Feng Z, Yuan X, Fares S, Loreto F, Li P, Hoshika Y, Paoletti E (2019b) Isoprene is more affected by climate drivers than monoterpenes: a meta-analytic review on plant isoprenoid emissions. Plant Cell Environ 42(6):1939-1949. https://doi. org/10.1111/pce.13535
Fernandez P, Hilker M (2007) Host plant location by Chrysomelidae. Basic Appl Ecol 8(2):97-116. https://doi.org/10.1016/j. baae.2006.05.001

Friedli A, Williams GR, Bruckner S, Neumann P, Straub L (2020) The weakest link: haploid honey bees are more susceptible to neonicotinoid insecticides. Chemosphere. https://doi.org/10.1016/j. chemosphere.2019.125145

Fuentes JD, Chamecki M, Roulston T, Chen B, Pratt KR (2016) Air pollutants degrade floral scents and increase insect foraging times. Atmos Environ 141:361-374. https://doi.org/10.1016/j. atmosenv.2016.07.002

Fuentes JD, Lerdau M, Atkinson R, Baldocchi D, Bottenheim JW, Ciccioli P, Lamb B, Geron C, Gu L, Guenther A, Sharkey TD, Stockwell W (2000) Biogenic hydrocarbons in the atmospheric boundary layer: a review. Bull Am Meteorol Soc 81(7):1537-1575

Fuentes JD, Roulston TH, Zenker J (2013) Ozone impedes the ability of a herbivore to find its host. Environ Res Lett. https://doi. org/10.1088/1748-9326/8/1/014048

Fürstenberg-Hägg J, Zagrobelny M, Bak S (2013) Plant defense against insect herbivores. Int J Mol Sci 14(5):10242-10297. https://doi. org/10.3390/ijms 140510242

Germinara GS, Pistillo M, Griffo R, Garonna AP, Di Palma A (2019) Electroantennographic responses of Aromia bungii (Faldermann, 1835) (Coleoptera, Cerambycidae) to a range of volatile compounds. Insects 10(9):274. https://doi.org/10.3390/insects100 90274

Girón-Calva PS, Li T, Blande JD (2016) Plant-plant interactions affect the susceptibility of plants to oviposition by pests but are disrupted by ozone pollution. Agric Ecosyst Environ 233:352-360. https://doi.org/10.1016/j.agee.2016.09.028

Glinwood R, Pettersson J, Ahmed E, Ninkovic V, Birkett M, Pickett J (2003) Change in acceptability of barley plants to aphids after exposure to allelochemicals from couch-grass (Elytrigia repens). J Chem Ecol 29(2):261-274. https://doi.org/10.1023/A:10226 87025416

Grulke NE, Heath RL (2020) Ozone effects on plants in natural ecosystems. Plant Biol 22(S1):12-37. https://doi.org/10.1111/plb.12971

Guenther A, Geron C, Pierce T, Lamb B, Harley P, Fall R, Genieser NB (2000) Natural emissions of non-methane volatile organic compounds, carbon monoxide, and oxides of nitrogen from North America. Atmos Environ 34:2205-2230. https://doi.org/10.1016/ S1352-2310(99)00465-3

Guenther A, Karl T, Harley P, Wiedinmyer C, Palmer PI, Geron C (2006) Estimates of global terrestrial isoprene emissions using MEGAN (model of emissions of gases and aerosols from nature). Atmos Chem Phys Discuss 6(11):3181-3210. https:// doi.org/10.5194/acp-6-3181-2006

Hamilton JG, Dermody O, Aldea M, Zangerl AR, Rogers A, Berenbaum MR, DeLucia EH (2005) Anthropogenic changes in tropospheric composition increase susceptibility of soybean to insect herbivory. Environ Entomol 34(2):479-485. https://doi. org/10.1603/0046-225X-34.2.479

Hauser MT (2014) Molecular basis of natural variation and environmental control of trichome patterning. Front Plant Sci 5(320):17. https://doi.org/10.3389/fpls.2014.00320

Heil M, Bueno JCS (2007) Within-plant signaling by volatiles leads to induction and priming of an indirect plant defense in nature. Proc Natl Acad Sci USA 104(13):5467-5472. https://doi.org/10.1073/ pnas.0610266104

Herms DA, Mattson WJ (1992) The dilemma of plants: to grow or defend. Q Rev Biol 67(3):283-335

Himanen SJ, Blande JD, Klemola T, Pulkkinen J, Heijari J, Holopainen JK (2010) Birch (Betula spp.) leaves adsorb and re-release volatiles specific to neighbouring plants - a mechanism for associational herbivore resistance? New Phytol 186(3):722-732. https ://doi.org/10.1111/j.1469-8137.2010.03220.x 
Holopainen JK, Blande JD (2013) Where do herbivore-induced plant volatiles go? Front Plant Sci 4:1-13. https://doi.org/10.1038/ s41598-020-68386-4

Holopainen JK, Gershenzon J (2010) Multiple stress factors and the emission of plant VOCs. Trends Plant Sci 15(3):176-184. https ://doi.org/10.1016/j.tplants.2010.01.006

Holton MK, Lindroth RL, Nordheim EV (2003) Foliar quality influences tree-herbivore-parasitoid interactions: effects of elevated $\mathrm{CO}_{2}, \mathrm{O}_{3}$, and plant genotype. Oecologia 137:233-244. https:// doi.org/10.1007/s00442-003-1351-z

Howe GA, Jander G (2008) Plant immunity to insect herbivores. Annu Rev Plant Biol 59(1):41-66. https://doi.org/10.1146/annur ev.arplant.59.032607.092825

Im U, Poupkou A, Incecik S, Markakis K, Kindap T, Unal A, Melas D, Yenigun O, Topcu S, Odman MT, Tayanc M, Guler M (2011) The impact of anthropogenic and biogenic emissions on surface ozone concentrations in Istanbul. Sci Total Environ 409(7):12551265. https://doi.org/10.1016/j.scitotenv.2010.12.026

Iovinella I, Pierattini EC, Bedini S, Dani FR, Guarino S, Lucchi A, Giannotti P, Cuzzupoli G, Girardi J, Conti B (2020) Semiochemicals for intraspecific communication of the fig weevil Aclees sp. Cf. foveatus (Coleoptera: Curculionidae): a first survey. Sci Rep 10(1):1-8. https://doi.org/10.1038/s41598-020-58004-8

Karabourniotis G, Liakopoulos G, Nikolopoulos D, Bresta P (2020) Protective and defensive roles of non-glandular trichomes against multiple stresses: structure-function coordination. J For Res 31(1):1-12. https://doi.org/10.1007/s11676-019-01034-4

Kearns CA, Inouye DW, Waser NM (1998) Endangered mutualisms: the conservation of plant-pollinator interactions. Annu Rev Ecol Syst 29:83-112. https://doi.org/10.1146/annurev.ecolsys.29.1.83

Kesselmeier J, Staudt M (1999) Biogenic volatile organic compounds (VOC): an overview on emission, physiology and ecology. J Atmos Chem 33:23-88. https://doi.org/10.1023/A:1006127516 791

Kessler A, Baldwin IT (2001) Defensive function of herbivore-induced plant volatile emissions in nature. Science 291(5511):21412144. https://doi.org/10.1126/science.291.5511.2141

Khaling E, Agyei T, Jokinen S, Holopainen JK, Blande JD (2020) The phytotoxic air-pollutant $\mathrm{O}_{3}$ enhances the emission of herbivoreinduced volatile organic compounds (VOCs) and affects the susceptibility of black mustard plants to pest attack. Environ Pollut 265:115030. https://doi.org/10.1016/j.envpol.2020.115030

Khaling E, Li T, Holopainen JK, Blande JD (2016) Elevated ozone modulates herbivore-induced volatile emissions of Brassica nigra and alters a tritrophic interaction. J Chem Ecol 42(5):368 381. https://doi.org/10.1007/s10886-016-0697-8

Khan MAH, Morris WC, Galloway M, Shallcross BMA, Percival CJ, Shallcross DE (2017) An estimation of the levels of stabilized criegee intermediates in the UK urban and rural atmosphere using the steady-state approximation and the potential effects of these intermediates on tropospheric oxidation cycles. Int J Chem Kinet 49(8):611-621. https://doi.org/10.1002/kin.21101

Killiny N, Jones SE (2017) Profiling of volatile organic compounds released from individual intact juvenile and mature citrus leaves. J Plant Physiol 208:47-51. https://doi.org/10.1016/j.jplph 2016.11.001

Kim S, Karl T, Guenther A, Tyndall G, Orlando J, Harley P, Rasmussen R, Apel E (2010) Emissions and ambient distributions of biogenic volatile organic compounds (BVOC) in a ponderosa pine ecosystem: interpretation of PTR-MS mass spectra. Atmos Chem Phys 10(4):1759-1771. https://doi.org/10.5194/ acp-10-1759-2010

Kim SY, Jiang X, Lee M, Turnipseed A, Guenther A, Kim JC, Lee SJ, Kim S (2013) Impact of biogenic volatile organic compounds on ozone production at the Taehwa research forest near Seoul, South
Korea. Atmos Environ 70(3):447-453. https://doi.org/10.1016/j. atmosenv.2012.11.005

Klein AM, Vaissière BE, Cane JH, Steffan-Dewenter I, Cunningham SA, Kremen C, Tscharntke T (2007) Importance of pollinators in changing landscapes for world crops. Proc R Soc B Biol Sci 274(1608):303-313. https://doi.org/10.1098/rspb.2006.3721

Klemola T, Ammunét T, Andersson T, Klemola N, Ruohomäki $\mathrm{K}$ (2012) Larval parasitism rate increases in herbivoredamaged trees: a field experiment with cyclic birch feeding moths. Oikos 121(10):1525-1531. https://doi.org/10.111 1/j.1600-0706.2011.20096.x

Kloth KJ, Thoen MPM, Bouwmeester HJ, Jongsma MA, Dicke M (2012) Association mapping of plant resistance to insects. Trends Plant Sci 17(5):311-319. https://doi.org/10.1016/j.tplan ts.2012.01.002

Koike T (1988) Leaf structure and photosynthetic performance as related to the forest succession of deciduous broad-leaved trees. Plant Spec Biol 3:77-87. https://doi. org/10.1111/j.1442-1984.1988.tb00173.x

Koike T, Matsuki S, Choi D, Matsumoto T, Watanabe Y, Maruyama Y (2006) Photosynthesis, leaf longevity and defense characteristics in trees of Betulaceae planted in northern Japan. Eurasian J For Res 9(2):69-78

Koike T, Watanabe M, Hoshika Y, Kitao M, Matsumura H, Funada R, Izuta T (2013) Effects of ozone on forest ecosystems in East and Southeast Asia. Dev Environm Sci 13:371-390. https://doi. org/10.1016/B978-0-08-098349-3.00017-7

Kopper BJ, Lindroth RL (2003) Effects of elevated carbon dioxide and ozone on the phytochemistry of aspen and performance of an herbivore. Oecologia 134:95-103. https://doi.org/10.1007/ s00442-002-1090-6

Krishnan S, Wiederkehr Guerra G, Bertrand D, Wertz-Kanounnikoff S, Kettle CJ (2020) The pollination services of forests - a review of forest and landscape interventions to enhance their cross-sectoral benefits. FAO and Bioversity International, Rome. https://doi. org/10.4060/ca9433en

Li G, Ishikawa Y (2006) Leaf epicuticular wax chemicals of the Japanese knotweed Fallopia japonica as oviposition stimulants for Ostrinia latipennis. J Chem Ecol 32(3):595-604. https://doi. org/10.1007/s10886-005-9022-7

Li L, Manning WJ, Tong L, Wang X (2015) Chronic drought stress reduced but not protected Shantung maple (Acer truncatum Bunge) from adverse effects of ozone $\left(\mathrm{O}_{3}\right)$ on growth and physiology in the suburb of Beijing, China. Environ Pollut 201:34-41. https://doi.org/10.1016/j.envpol.2015.02.023

Li P, De Marco A, Feng Z, Anav A, Zhou D, Paoletti E (2017) Nationwide ground-level ozone measurements in China suggest serious risks to forests. Environ Pollut 237:803-813. https://doi. org/10.1016/j.envpol.2017.11.002

Li S, Tosens T, Harley PC, Jiang Y, Kanagendran A, Grosberg M, Jaamets K, Niinemets Ü (2018) Glandular trichomes as a barrier against atmospheric oxidative stress: relationships with ozone uptake, leaf damage, and emission of LOX products across a diverse set of species. Plant Cell Environ 41(6):1263-1277. https ://doi.org/10.1111/pce.13128

Lindroth RL (2010) Impacts of elevated atmospheric $\mathrm{CO}_{2}$ and $\mathrm{O}_{3}$ on forests: phytochemistry, trophic interactions, and ecosystem dynamics. J Chem Ecol 36(1):2-21. https://doi.org/10.1007/ s10886-009-9731-4

Liu N, Ren W, Li X, Ma X, Zhang Y, Li B (2019) Distribution and urban-suburban differences in ground-level ozone and its precursors over Shenyang, China. Meteorol Atmos Phys 131(3):669679. https://doi.org/10.1007/s00703-018-0598-1

Llusià J, Peñuelas J, Gimeno BS (2002) Seasonal and species-specific response of VOC emissions by Mediterranean woody plant to 
elevated ozone concentrations. Atmos Environ 36(24):39313938. https://doi.org/10.1016/S1352-2310(02)00321-7

Loreto F, Bagnoli F, Fineschi S (2009) One species, many terpenes: matching chemical and biological diversity. Trends Plant Sci 14(8):416-420. https://doi.org/10.1016/j.tplants.2009.06.003

Manninen AM, Holopainen T, Lyytikäinen-Saarenmaa P, Holopainen JK (2000) The role of low-level ozone exposure and mycorrhizas in chemical quality and insect herbivore performance on Scots pine seedlings. Glob Chang Biol 6:111-121. https://doi.org/10. 1046/j.1365-2486.2000.00290.x

Manosalva L, Pardo F, Perich F, Mutis A, Parra L, Ortega F, Isaacs R, Quiroz A (2011) Behavioral responses of clover root borer to long-chain fatty acids from young red clover (Trifolium pratense) roots. Environ Entomol 40(2):399-404. https://doi.org/10.1603/ EN10008

Masui N, Mochizuki T, Tani A, Matsuura H, Agathokleous E, Watanabe T, Koike T (2020) Does ozone alter the attractiveness of Japanese white birch leaves to the leaf beetle Agelastica coerulea via changes in biogenic volatile organic compounds (BVOCs): an examination with the Y-tube test. Forests 11:58. https://doi. org/10.3390/f11010058

Matsuki S, Sano Y, Koike T (2004) Chemical and physical defence in early and late leaves in three heterophyllous birch species native to northern Japan. Ann Bot 93(2):141-147. https://doi. org/10.1093/aob/mch022

Matyssek R, Wieser G, Calfapietra C, De Vries W, Dizengremel P, Ernst D, Jolivet Y, Mikkelsen TN, Mohren GMJ, Le Thiec D, Tuovinen JP, Weatherall A, Paoletti E (2012) Forests under climate change and air pollution: gaps in understanding and future directions for research. Environ Pollut 160(1):57-65. https://doi. org/10.1016/j.envpol.2011.07.007

McCormick AC, Unsicker SB, Gershenzon J (2012) The specificity of herbivore-induced plant volatiles in attracting herbivore enemies. Trends Plant Sci 17(5):303-310. https://doi.org/10.1016/j.tplan ts.2012.03.012

McFrederick QS, Fuentes JD, Roulston T, Kathilankal JC, Lerdau M (2009) Effects of air pollution on biogenic volatiles and ecological interactions. Oecologia 160(3):411-420. https://doi. org/10.1007/s00442-009-1318-9

Mishra S, Sihag RC (2010) Efficacy of some chemicals and additives as bee repellents against two honeybee species, Apis mellifera L. and Apis florea F. in semi-field trials. J Apic Sci 54(1):21-34

Miyama T, Tobita H, Uchiyama K, Yazaki K, Ueno S, Saito T, Matsumoto A, Kitao M, Izuta T (2018) Differences in monoterpene emission characteristics after ozone exposure between three clones representing major gene pools of Cryptomeria japonica. J Agric Meteorol 74(3):102-108. https://doi.org/10.2480/agrme t.D-17-00043

Mofikoya AO, Kivimäenpää M, Blande JD, Holopainen JK (2018) Ozone disrupts adsorption of Rhododendron tomentosum volatiles to neighbouring plant surfaces, but does not disturb herbivore repellency. Environ Pollut 240:775-780. https://doi. org/10.1016/j.envpol.2018.05.031

Moser-Reischl A, Rötzer T, Biber P, Ulbricht M, Uhl E, Qu L, Koike T, Pretzsch H (2019) Growth of Abies sachalinensis along an urban gradient affected by environmental pollution in Sapporo, Japan. Forests 10(8):707. https://doi.org/10.3390/f10080707

Mukherjee A, Barik A (2014) Long-chain free fatty acids from Momordica cochinchinensis Spreng flowers as allelochemical influencing the attraction of Aulacophora foveicollis Lucas (Coleoptera: Chrysomelidae). Allelopath J 33(2):255-266

Mukherjee A, Sarkar N, Barik A (2014) Long-chain free fatty acids from Momordica cochinchinensis leaves as attractants to its insect pest, Aulacophora foveicollis Lucas (Coleoptera: Chrysomelidae). J Asia Pac Entomol 17(3):229-234. https:// doi.org/10.1016/j.aspen.2014.01.010
Nagashima T, Sudo K, Akimoto H, Kurokawa J, Ohara T (2017) Long-term change in the contributions of various source regions to surface ozone over Japan. Atmos Chem Phys Discuss 17:8231-8246. https://doi.org/10.5194/acp-2016-1087

Nakada LYK, Urban RC (2020) COVID-19 pandemic: impacts on the air quality during the partial lockdown in São Paulo state, Brazil. Sci Total Environ 730:139087. https://doi.org/10.1016/j. scitotenv.2020.139087

Oksanen E (2018) Trichomes form an important first line of defence against adverse environment-new evidence for ozone stress mitigation. Plant Cell Environ 41(7):1497-1499. https://doi. org/10.1111/pce. 13187

Ollerton J, Winfree R, Tarrant S (2011) How many flowering plants are pollinated by animals? Oikos 120(3):321-326. https://doi. org/10.1111/j.1600-0706.2010.18644.x

Paoletti E, De Marco A, Beddows DCS, Harrison RM, Manning WJ (2014) Ozone levels in European and USA cities are increasing more than at rural sites, while peak values are decreasing. Environ Pollut 192:295-299. https://doi.org/10.1016/j.envpo 1.2014.04.040

Parr MJ, Tran BMD, Simmonds MSJ, Kite GC, Credland PF (1998) Influence of some fatty acids on oviposition by the bruchid beetle Callosobruchus maculatus. J Chem Ecol 24(10):15771593. https://doi.org/10.1023/A:1020894410107

Penuelas J, Llusia J (2001) The complexity of factors driving volatile organic compound emissions by plants. Biol Plant 44(4):481487. https://doi.org/10.1023/A:1013797129428

Pinto DM, Blande JD, Nykänen R, Dong WX, Nerg AM, Holopainen JK (2007a) Ozone degrades common herbivore-induced plant volatiles: does this affect herbivore prey location by predators and parasitoids? J Chem Ecol 33(4):683-694. https://doi. org/10.1007/s10886-007-9255-8

Pinto DM, Blande JD, Souza SR, Nerg AM, Holopainen JK (2010) Plant volatile organic compounds (VOCs) in ozone $\left(\mathrm{O}_{3}\right)$ polluted atmospheres: the ecological effects. J Chem Ecol 36(1):22-34. https://doi.org/10.1007/s10886-009-9732-3

Pinto DM, Nerg AM, Holopainen JK (2007b) The role of ozone-reactive compounds, terpenes, and green leaf volatiles (GLVs), in the orientation of Cotesia plutellae. J Chem Ecol 33(12):22182228. https://doi.org/10.1007/s10886-007-9376-0

Poorter H, Niinemets Ü, Poorter L, Wright IJ, Villar R (2009) Causes and consequences of variation in leaf mass per area (LMA): a meta-analysis. New Phytol 182(3):565-588. https://doi.org/1 0.1111/j.1469-8137.2009.02830.x

Proesmans W, Bonte D, Smagghe G, Meeus I, Verheyen K (2019) Importance of forest fragments as pollinator habitat varies with season and guild. Basic Appl Ecol 34:95-107. https:// doi.org/10.1016/j.baae.2018.08.004

Prozherina N, Freiwald V, Rousi M, Oksanen E (2003) Interactive effect of springtime frost and elevated ozone on early growth, foliar injuries and leaf structure of birch (Betula pendula). New Phytol 159(3):623-636. https://doi.org/10.104 6/j.1469-8137.2003.00828.x

Rautio P, Markkola A, Martel J, Tuomi J, Härmä E, Kuikka K, Siitonen A, Riesco IL, Roitto M (2002) Developmental plasticity in birch leaves: defoliation causes a shift from glandular to nonglandular trichomes. Oikos 98(3):437-446. https://doi.org /10.1034/j.1600-0706.2002.980308.x

Rivers JW, Galbraith SM, Cane JH, Schultz CB, Ulyshen MD, Kormann UG (2018) A review of research needs for pollinators in managed conifer forests. J For 116(6):563-572. https://doi. org/10.1093/jofore/fvy052

Saitanis CJ, Agathokleous E, Burkey K, Hung YT (2020) Ground level ozone profile and the role of plants as sources and sinks. In: Hung YT, Wang LK, Shammas N (eds) Handbook of 
environment and waste management, vol 3. World Scientific Publishing, Singapore, p p1055

Sakikawa T, Shi C, Nakamura M, Watanabe M, Oikawa M, Satoh F, Koike T (2016) Leaf phenology and insect grazing of Japanese white birch saplings grown under free-air ozone exposure. $\mathrm{J}$ Agric Meteorol 72(2):80-84. https://doi.org/10.2480/agrme t.D-14-00031

Saunier A, Blande JD (2019) The effect of elevated ozone on floral chemistry of Brassicaceae species. Environ Pollut 255:113257. https://doi.org/10.1016/j.envpol.2019.113257

Schoonhoven LM, van Loon JJA, Dicke M (2005) Insect-plant biology. Oxford University Press, New York, p 448

Schultz MG, Schröder S, Lyapina O, Cooper O, Galbally I, Petropavlovskikh I, von Schneidemesser E, Tanimoto H, Elshorbany Y, Naja M, Seguel R, Dauert U, Eckhardt P, Feigenspahn S, Fiebig M, Hjellbrekke A-G, Hong Y-D, Kjeld PC, Koide H, Lear G, Tarasick D, Ueno M, Wallasch M, Baumgardner D, Chuang M-T, Gillett R, Lee M, Molloy S, Moolla R, Wang T, Sharps K, Adame JA, Ancellet G, Apadula F, Artaxo P, Barlasina M, Bogucka M, Bonasoni P, Chang L, Colomb A, Cuevas E, Cupeiro M, Degorska A, Ding A, Fröhlich M, Frolova M, Gadhavi H, Gheusi F, Gilge S, Gonzalez MY, Gros V, Hamad SH, Helmig D, Henriques D, Hermansen O, Holla R, Huber J, Im U, Jaffe DA, Komala N, Kubistin D, Lam K-S, Laurila T, Lee H, Levy I, Mazzoleni C, Mazzoleni L, McClure-Begley A, Mohamad M, Murovic M, Navarro-Comas M, Nicodim F, Parrish D, ReadReid KAN, Ries L, Saxena P, Schwab JJ, Scorgie Y, Senik I, Simmonds P, Sinha V, Skorokhod A, Spain G, Spangl W, Spoor R, Springston SR, Steer K, Steinbacher M, Suharguniyawan E, Torre P, Trickl T, Weili L, Weller R, Xu X, Xue L, Zhiqiang M (2017) Tropospheric ozone assessment report: database and metrics data of global surface ozone observations. Elem Sci Anth 5:58. https://doi. org/10.1525/elementa.244

Shang B, Feng Z, Li P, Yuan X, Xu Y, Calatayud V (2017) Ozone exposure- and flux-based response relationships with photosynthesis, leaf morphology and biomass in two poplar clones. Sci Total Environ 603-604:185-195. https://doi.org/10.1016/j. scitotenv.2017.06.083

Sharma A, Sandhi RK, Reddy GVP (2019) A review of interactions between insect biological control agents and semiochemicals. Insects 10(12):439. https://doi.org/10.3390/insects10120439

Sharma S, Zhang M, Anshika GJ, Zhang H, Kota SH (2020) Effect of restricted emissions during COVID-19 on air quality in India. Sci Total Environ 728:138878. https://doi.org/10.1016/j.scito tenv. 2020.138878

Shimoda T, Ozawa R, Arimura G, Takabayashi J, Nishioka T (2002) Olfactory responses of two specialist insect predators of spider mites toward plant volatiles from lima bean leaves induced by jasmonic acid and/or methyl salicylate. Appl Entomol Zool 37(4):535-541. https://doi.org/10.1303/aez.2002.535

Shimoda T, Takabasyashi J, Ashihara W, Takafuji A (1997) Response of predatory insect Scolothrips takahashii toward herbivoreinduced plant volatiles under laboratory and field conditions. J Chem Ecol 23(8):2033-2048. https://doi.org/10.1023/ B:JOEC.0000006487.49221.df

Sicard P, De MA, Agathokleous E, Feng Z, Xu X, Paoletti E, Jaime J, Rodriguez D, Calatayud V (2020) Amplified ozone pollution in cities during the COVID-19 lockdown. Sci Total Environ. https://doi.org/10.1016/j.scitotenv.2020.139542

Šimpraga M, Ghimire RP, Van Der Straeten D, Blande JD, Kasurinen A, Sorvari J, Holopainen T, Adriaenssens S, Holopainen JK, Kivimäenpää M (2019) Unravelling the functions of biogenic volatiles in boreal and temperate forest ecosystems. Eur J For Res 138(5):763-787. https://doi.org/10.1007/s10342-01901213-2
Šimpraga M, Takabayashi J, Holopainen JK (2016) Language of plants: where is the word? J Integr Plant Biol 58(4):343-349. https://doi.org/10.1111/jipb.12447

Simpson JR, McPherson EG (2011) The tree BVOC index. Environ Pollut 159(8-9):2088-2093. https://doi.org/10.1016/j.envpo 1.2011 .02 .034

Sitch S, Cox PM, Collins WJ, Huntingford C (2007) Indirect radiative forcing of climate change through ozone effects on the land-carbon sink. Nature 448:791-794. https://doi.org/10.1038/ nature 06059

Sugai T, Okamoto S, Agathokleous E, Masui N, Satoh F, Koike T (2020) Leaf defense capacity of Japanese elm (Ulmus davidiana var. japonica) seedlings subjected to a nitrogen loading and insect herbivore dynamics in a free air ozone-enriched environment. Environ Sci Pollut Res 27(3):3350-3360. https ://doi.org/10.1007/s11356-019-06918-w

Sun JG, Huang LQ, Wang CZ (2012) Electrophysiological and behavioral responses of Helicoverpa assulta (Lepidoptera: Noctuidae) to tobacco volatiles. Arthropod Plant Interact 6(3):375-384. https://doi.org/10.1007/s11829-012-9190-7

Takabayashi J, Dicke M (1992) Response of predatory mites with different rearing histories to volatiles of uninfested plants. Entomol Exp Appl 64(2):187-193. https://doi. org/10.1111/j.1570-7458.1992.tb01608.x

Takabayashi J, Shiojiri K (2019) Multifunctionality of herbivoryinduced plant volatiles in chemical communication in tritrophic interactions. Curr Opin Insect Sci 32:110-117. https ://doi.org/10.1016/j.cois.2019.01.003

Takahashi M, Feng Z, Mikhailova TA, Kalugina OV, Shergina OV, Afanasieva L, Heng RKJ, Majid NMA, Sase H (2020) Air pollution monitoring and tree and forest decline in East Asia: a review. Sci Total Environ. https://doi.org/10.1016/j.scito tenv. 2020.140288

Tani A, Ohno T, Saito T, Ito S, Yonekura T, Miwa M (2017) Effects of ozone on isoprene emission from two major Quercus species native to east Asia. J Agric Meteorol 73(4):195-202. https:// doi.org/10.2480/agrmet.D-17-00022

Tian D, Tooker J, Peiffer M, Chung SH, Felton GW (2012) Role of trichomes in defense against herbivores: comparison of herbivore response to woolly and hairless trichome mutants in tomato (Solanum lycopersicum). Planta 236(4):1053-1066. https://doi.org/10.1007/s00425-012-1651-9

Timilsena BP, Seidl-Adams I, Tumlinson JH (2020) Herbivore-specific plant volatiles prime neighboring plants for nonspecific defense responses. Plant Cell Environ 43(3):787-800. https:// doi.org/10.1111/pce.13688

Trowbridge AM, Stoy PC (2013) BVOC-mediated plant-herbivore interactions. In: Niinemets Ü, Monson RK (eds) Biology, controls and models of tree volatile organic compound emissions. Springer, Dordrecht, pp 21-46

Vermeij GJ (2015) Plants that lead: do some surface features direct enemy traffic on leaves and stems? Biol J Linn Soc 116(2):288294. https://doi.org/10.1111/bij.12592

Vreysen MJB (2005) Monitering sterile and wild insects in area-wide integrated pest manegement programs. In: Dyck VA, Hendrichs J, Robinson AS (eds) Sterile insect technique: principles and practice in area-wide integrated pest management. Springer, Dordrecht, pp 325-361

War AR, Paulraj MG, Ahmad T, Buhroo AA, Hussain B, Ignacimuthu S, Sharma HC (2012) Mechanisms of plant defense against insect herbivores. Plant Signal Behav 7(10):13061320. https://doi.org/10.4161/psb.21663

Watanabe M, Hoshika Y, Koike T, Izuta T (2017) Effects of ozone on Japanese trees. In: Izuta T (ed) Air pollution impacts on plants in East Asia. Springer, Tokyo, pp 73-100 
Xu S, He X, Burkey K, Chen W, Li P, Li Y, Bo Li, Wang Y (2019) Ethylenediurea (EDU) pretreatment alleviated the adverse effects of elevated $\mathrm{O}_{3}$ on Populus alba "Berolinensis" in an urban area. J Environ Sci 84:42-50. https://doi.org/10.1016/j.jes.2019.04.018

Xu S, He X, Chen W, Huang Y, Zhao Y, Li B (2015) Differential sensitivity of four urban tree species to elevated $\mathrm{O}_{3}$. Urban Urban Green 14(4):1166-1173. https://doi.org/10.1016/j. ufug.2015.10.015

Yamasaki M, Kikuzawa K (2003) Temporal and spatial variations in leaf herbivory within a canopy of Fagus crenata. Oecologia 137(2):226-232. https://doi.org/10.1007/s00442-003-1337-x
Yuan X, Li S, Feng Z, Xu Y, Shang B, Fares S, Paoletti E (2020) Response of isoprene emission from poplar saplings to ozone pollution and nitrogen deposition depends on leaf position along the vertical canopy profile. Environ Pollut 265:114909. https:// doi.org/10.1016/j.envpol.2020

Publisher's Note Springer Nature remains neutral with regard to jurisdictional claims in published maps and institutional affiliations. 